\title{
Lethal mutations induced in Drosophila melanogaster by direct or indirect action of pteridines
}

\author{
C. l'Hélias ${ }^{1}$, J. Proust ${ }^{2}$, I. Ebels ${ }^{3}$ and C.A. Salemink ${ }^{3}$ \\ ' Laboratoire de Biologie Evolutive, 91190 Gif -sur-Yvette (France), ${ }^{2}$ Laboratoire de Génétique II, Université de Paris-Sud, Bât. 400, \\ 91405 Orsay Cedex (France) and ${ }^{3}$ Laboratory of Organic Chemistry, University of Utrecht, Utrecht (The Netherlands)
}

(Received 14 October 1982)

(Revision received 25 April 1984)

(Accepted 2 May 1984)

\section{Summary}

The experiments described in this paper show that synthetic pteridines, especially biopterin and pterin, injected directly into Drosophila melanogaster induce recessive lethals. On the contrary, D-neopterin seems to have little effect.

A mutagenic effect has previously been shown for an extract of Pieris brassicae in diapause, treated with these pteridines and tetrahydrofolic acid $\left(\mathrm{FH}_{4}\right)$.

It appears that chromosome II is more sensitive to these mutagenic treatments than chromosome $\mathrm{X}$.

Previous experiments have shown that synthetic pteridines (biopterin, pterin and neopterin) can influence the control of the development and differentiation of insects, especially in animals which are sensitive to variations in environmental factors, such as photoperiod and temperature (Pieris brassicae).

By a still unknown mechanism, pteridines seem to interfere with the control of gonadal development. We have assumed that the imbalance in this regulation caused by injection of pteridines into diapausing chrysalids of Pieris brassicae, involves a modification of the retention or the release of polypeptic hormones of the pars intercerebralis.

Injection of an extract of diapausing chrysalids of Pieris previously treated with pteridines and tetrahydrofolic acid induces recessive lethal and visible mutations (L'Hélias, 1966, 1970, 1972, 1973, 1975; L'Hélias and Proust, 1982).

Our experiments were devised to test whether the same mutagenic action were observed with pteridines injected directly into Drosophila melanogaster larvae. We tested 3 pteridines purified by Ebels and Salemink.

\section{Materials and methods}

\section{Experimental protocol}

(1) Indirect treatment. Treatment and extraction of Pieris brassicae were carried out according to previously described methods (L'Hélias, 1972, 1973, 1975). The Drosophila larvae of third instar of wild type (Oregon) received a fraction of an extract of diapausing Pieris brassicae chrysalids, which had been treated with pteridines and $\mathrm{FH}_{4}$. These extracts were purified by sucrose density gradient centrifugation; $0.1 \mu \mathrm{l}$ of a solution $\times 10^{6}$, resulting from one of the fractions, corresponding to the genetically active sedimentation zone $18 \mathrm{~S}-28 \mathrm{~S}$, was injected.

(2) Direct treatment. Pteridines were diluted in Ringer. Third-instar larvae of Drosophila were injected with this solution of pteridines: $1 \mathrm{pg}$ in 0.1 $\mu l$ per larva. 
(3) Control. A control without treatment was used as reference for the two series, showing the spontaneous mutation rate in the Oregon wild strain.

\section{Pteridines}

The following pteridines were used for experiments: 6-L-erythrobiopterin (with about 18\% of 7-L-erythrobiopterin) was a generous gift from $\mathrm{Dr}$. A.R. Mass (Smith, Kline and French Laboratories, Philadelphia, PA, U.S.A.). Pterin base, and Dneopterin were obtained from Fluka AG, Chemische Fabrik CH 3470, Switzerland. Reduced pterins were made according to a previously published method (Balemans et al., 1980). Fig. 1 presents the chemical formulae of the 3 pterins and their reduced forms. There is as yet no method available for separating the different forms (reduced and not reduced) of pteridines contained in the extract.

\section{Genetic analysis: Detection of recessive lethals}

Chromosome $X$. The Muller 5 technique was used. Females and males treated with pteridines or extract of chrysalids previously treated with the same pteridines, were crossed individually with 3 spouses of Basc strain. Two generations of breeding were necessary to detect sex-linked lethals.

Chromosome II. Two different methods were used to detect lethals: The balanced dominant lethal strains $(\mathrm{Cy} / \mathrm{Pm} ; \mathrm{H} / \mathrm{Sb} \mathrm{C})$, or a more devel- oped technique, the Sifter method (Muller, 1951). Females or males developing from treated larvae were crossed individually to 3 spouses of one of these strains. Three generations were necessary to detect lethals.

300 larvae were injected in each experiment. The percentage of survivors varied between 1 and $2 \%$, showing that these treatments are extremely drastic.

\section{Results}

\section{(1) Chromosome $X$}

Table 1 shows that the frequency of induced sex-linked lethals in larvae did not increase significantly over the spontaneous frequency.

\section{(2) Chromosome II}

Results are presented in Table 2. Allelism tests were carried out to determine the exact number of lethals of independent origin. Clusters of lethals can be induced first because the treatments are very drastic, and secondly, because the female and male larvae of third instar do not have the same germinal cells population (ovaries only at the oogonial stage, testes at all spermatogenesis stages). Clusters of lethals are more probable in progeny of treated female larvae.

The results of complementation tests are as follows:

Some intracrosses between lethals obtained from

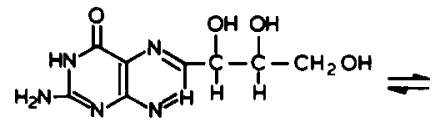

NEOPTERIN<smiles>C=C=C</smiles>

BIOPTERIN

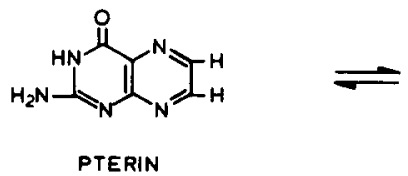

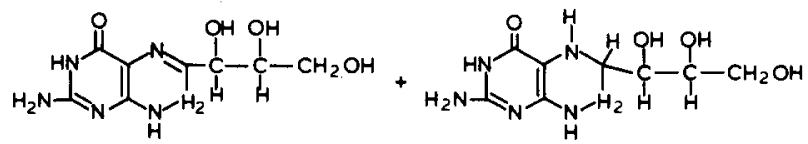

7-8 DIHYORONEOPTERIN

5-6-7-8 TETRAHYDRONEOPTERIN

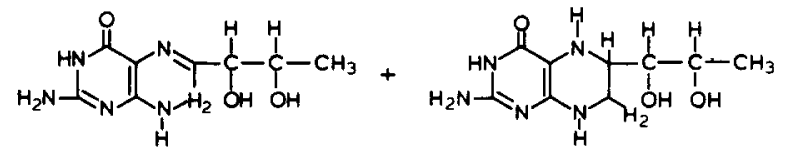

7-8 DIHYDROBIOPTERIN

5-6-7-8 TETRAHYDROBIOPTERIN

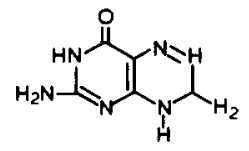<smiles>Nc1nc2c(c(=O)[nH]1)NCCC2</smiles>

5-6-7-8 TETRAHYDROPTERIN

Fig. 1. Chemical formulae of the 3 pteridines (biopterin, pterin, neopterin) and their reduced forms. 
TABLE 1

SEX-LINKED LETHALS INDUCED IN Drosophila melanogaster AFTER DIRECT AND INDIRECT TREATMENTS WITH PTERIDINES

\begin{tabular}{llllll}
\hline $\begin{array}{l}\text { Treatments } \\
\text { (pooled } \\
\text { results) }\end{array}$ & $\begin{array}{l}\text { Number of } \\
\text { treated } \\
\text { larvae }\end{array}$ & $\begin{array}{l}\text { Number of } \\
\text { survivors }\end{array}$ & $\begin{array}{l}\text { Number of } \\
\text { tested } \\
\text { chromosomes }\end{array}$ & $\begin{array}{l}\text { Number of } \\
\text { induced } \\
\text { lethals }\end{array}$ & $\begin{array}{l}\text { Percentage of } \\
\text { lethals with } \\
\text { confidence interval }\end{array}$ \\
\hline $\begin{array}{l}\text { (a) Direct treatment } \\
\text { Biopterin }\end{array}$ & 300 & 6 & 248 & 1 & $0.4(0.0-2.2)$ \\
$\begin{array}{l}\text { Pterin } \\
\text { Neopterin }\end{array}$ & 300 & 4 & 198 & 1 & 0.5 \\
$(0.0-2.8)$ \\
(b) Indirect treatment & 300 & 8 & 191 & 0 & $0.0(0.0-1.9)$ \\
Biopterin & & & & & 0.0 \\
Pterin & 300 & 10 & 167 & 0 & $0.0-2.1)$ \\
Neopterin & 300 & 5 & 128 & 1 & $0.0-4.4)$ \\
Control without treatment & 300 & 7 & 153 & 0 & $0.0-2.3)$ \\
\hline
\end{tabular}

the same larvae were positive. Often, lethals appeared in small clusters of $2-4$, suggesting that premeiotic events had occurred. 5 clusters were observed ( 3 in direct treatments, 2 in indirect treatments).

The mutations in cluster are included in Table 2 , columns 5 and 6 . The standard errors for muta- tions of common origin were calculated according to Muller's formula, $S^{2} p=q\left(r^{2} \cdot I r\right) / n^{2}$, where $r=$ cluster size and $I r=$ number of clusters of size $r$. Columns 7 and 8 present the number of lethals of independent origin and the percentage with the confidence interval, calculated from normal standard error, $S^{2}=p(1-p) / n$, except when (see

TABLE 2

RECESSIVE LETHALS INDUCED ON CHROMOSOME II OF Drosophila melanogaster AFTER DIRECT AND INDIRECT TREATMENTS WITH PTERIDINES

\begin{tabular}{|c|c|c|c|c|c|c|c|c|}
\hline \multirow[t]{2}{*}{ Treatments } & \multirow{2}{*}{$\begin{array}{l}\text { Number of } \\
\text { treated } \\
\text { larvae }\end{array}$} & \multicolumn{2}{|c|}{ Survivors } & \multirow{2}{*}{$\begin{array}{l}\text { Number of } \\
\text { tested } \\
\text { chromosomes }\end{array}$} & \multirow{2}{*}{$\begin{array}{l}\text { Total mutation } \\
\text { clusters included }\end{array}$} & \multirow{2}{*}{$\begin{array}{l}\text { Total } \\
\text { mutations } \\
(\%)\end{array}$} & \multirow{2}{*}{$\begin{array}{l}\text { Number of } \\
\text { lethals of } \\
\text { independent } \\
\text { origin }\end{array}$} & \multirow{2}{*}{$\begin{array}{l}\text { Lethals of } \\
\text { independent origin } \\
\text { with confidence } \\
\text { interval }(\%)\end{array}$} \\
\hline & & $N$ & $\%$ & & & & & \\
\hline
\end{tabular}

(a) Direct treatment

$\begin{array}{lrrrrrrrrr}\text { Biopterin } & 300 & 5 & 1.7 & 102 & 21 & \left\{\begin{array}{l}7 \text { singles } \\ 2 \text { clusters of } 3 \\ 4 \text { clusters of } 2\end{array}\right. & 20.6 \pm 5.6 & 13 & 12.7(6.8-19.3) \\ \text { Pterin } & 300 & 2 & 0.6 & 31 & 2 & 2 \text { singles } & 6.5 \pm 4.4 & 2 & 0.5(0.8-15.3) \\ \text { Neopterin } & 300 & 4 & 1.3 & 0 & 0 & & 0.0 & 0 & 0.0(0.0-4.9)\end{array}$

(b) Indirect treatment

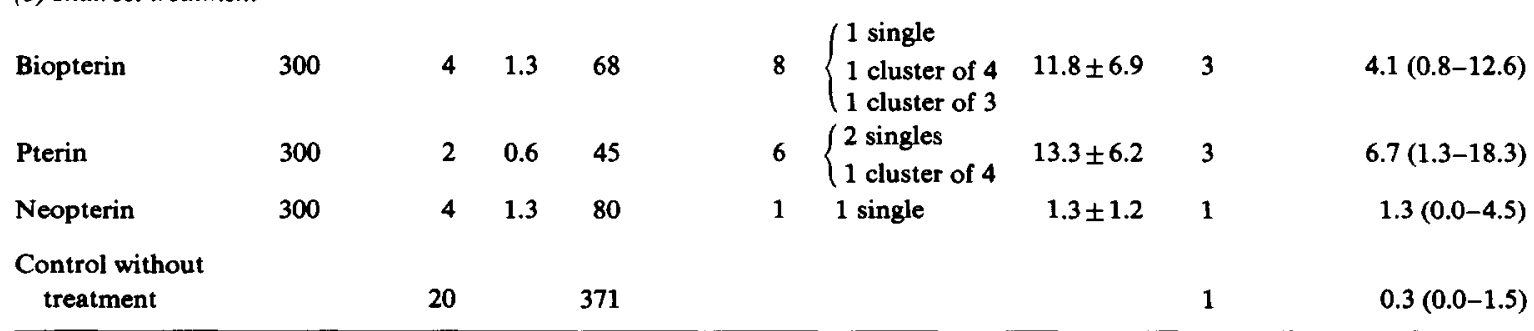

a A standard error according to Muller (1952). 


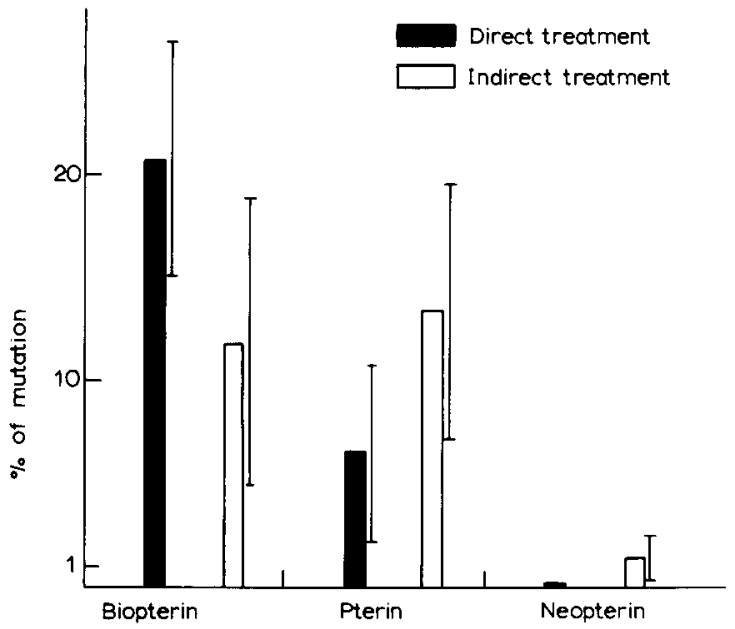

Fig. 2. Percentage mutagenicity of biopterin, pterin and neopterin using direct and indirect treatments.

Lamotte, 1962) the percentage is near 0 or 1.

The intercrosses between lethals obtained in different larvae were negative.

None of the experiments produced a sufficient number of survivors to allow any differences between female and male larvae to be established.

The main results are summarized in Fig. 2.

It appears that in each series (direct and indirect treatments) biopterin and pterin were both effective. On the contrary, neopterin seems to have had no effect at all.

In previous works, we observed a mutagenic effect of biopterin on the third chromosome, but only with the indirect treatment: $4.1 \% \pm 1.8$ of recessive lethals, control $0.4 \% \pm 0.5$ (see L'Hélias et al., 1982). Unfortunately, the direct injection of biopterin into larvae was not carried out.

\section{Discussion}

The facts observed may be summed up as follows:

(1) Direct and indirect treatments with biopterin and pterin induce recessive lethals in Drosophila melanogaster. Neopterin seems to have little or no effect at all.

(2) The increase in mutation frequency is significant for chromosome II but not for chromosome $\mathrm{X}$, suggesting a distinct response depending on the chromosome.

(1) The examination of the chemical structure of these 3 pteridines shows that they differ with regard to the presence or absence of a lateral sugar chain (biopterin and neopterin on the one hand and pterin on the other hand) (see Fig. 1). In biopterin, the primary alcohol group is replaced by a methyl group. Their important participation in the transfer of the methyl radical to uracil is known for the synthesis of desoxyribonucleoside, thymine catalysed by formyl hydrofolic acid $\left(\mathrm{fFH}_{4}\right)$ which has a specific role in DNA synthesis. The pteridines are unstable in light, particularly in the reduced form, where they become electron or hydrogen carriers in the enzymatic reactions controlling hormone or neurohormone synthesis.

In vertebrates, Ebels et al. (1979) and Ebels (1979) have shown the existence in vivo of biopterin in the active antigonadotropic fraction of the pineal gland. This fraction acts on gonadal regulation via the hypothalamus-hypophysis, through a still unknown mechanism.

In diapausing Pieris brassicae larvae, L'Hélias et al. (1982) have discovered a storage of neurosecretion in the pars intercerebralis after biopterin treatment suggesting a hormonal regulation system in insect brain. In both cases, pteridines seem to interfere with the regulation of reproduction, probably at the DNA level.

Sapunov (1981) has shown an effect of juvenile hormone analogs on mutation frequency in Drosophila melanogaster. These substances are able to induce recessive lethals. The author suggests that the endocrine system is perhaps the natural regulator system of mutagenesis in the higher organisms.

The very small concentration of pteridines used in our experiments $(1 \mathrm{pg} / 0.1 \mu \mathrm{l})$ is very close to the biological concentration. At such low concentration, pteridines may act rather on hormonal regulation than at the DNA level.

One hypothesis is that the experimental perturbation of hormonal regulation created by treatment with pteridines in injected Drosophila larvae may modify the cytoplasmic state. These modifications of the hormonal regulatory system may lead to the mobility of particular DNA sequences (Campbell, 1980), and consequently induce recessive lethal mutations. Many mobile sequences are present in about one-sixth of the Drosophila ge- 
nome. The transposition of such sequences is normally repressed in a strain but may be greatly enhanced by modification of the cytoplasmic state. The role of pteridines may be to promote the start of complex processes resulting in the mobility of these DNA sequences.

The second hypothesis is that pteridines, like many mutagens, induce modifications in DNA during gametogenesis which could disturb the reading of the genetic message and lead to lethals. These modifications could be produced in regulating genes as in structural genes. In both cases, the lethal effect could be the consequence of lack of one enzyme acting on DNA replication or repair. Both hypotheses remain to be tested.

(2) The last point to be discussed is the difference observed in sensitivity between chromosomes X and II. Mathew (1965) has shown that calf thymus DNA mixed with larvae food of Drosophila melanogaster induced lethal recessive mutations preferentially in the second chromosome. A regional specificity of DNA action has been reported by Gershenson (1965) in the lobe region of the 2nd chromosome, and by Fahmy and Fahmy (1963) in the proximal region of the 4th chromosome, preferentially to the $\mathrm{X}$ chromosome. In the first case, DNA was mixed in with the food; in the second case, it was injected. If autosomal chromosomes contain such vulnerable regions and not the $\mathrm{X}$ chromosome, this would explain the much weaker response of the latter treatment.

Sapunov (1981), with the LA strain, has also observed no mutator effect in the $\mathrm{X}$ chromosome, but a significant increase in the mutation frequency of the 2 nd chromosome. In spite of the lack of lethal clusters between larvae, we still cannot dismiss the hypothesis that specific regions exist.

In conclusion, the injection into Drosophila melanogaster larvae of biopterin or pterin has a similar mutagenic effect as an extract of diapausing Pieris brassicae treated with the same pteridines. These results confirm that in the indirect treatment, the role of pteridines is primordial in the mutagenic process.

\section{Acknowledgements}

We thank Prof. Sobels and Auerbach for their useful suggestions.

\section{References}

Balemans, M.G.M., J. Van Benthem, W.C. Le Gerstee, A. De Moree, H.J.P.M. Noteborn and I. Ebels (1980) The influence of some pterins on the circadian rhythmicity of hydroxyindole- $O$-methyl transferase in the pineal gland of 42-day-old male Wistar rats, Reprod. Nutr. Develop., 20, 1051-1060.

Campbell, A. (1980) Some general questions about movable elements and their implications, Cold Spring Harbor Symp. Quant. Biol., 45, 619-628.

Ebels, I. (1979) A chemical study of some biologically active pineal fractions in the pineal gland of vertebrate including man, Progr. Brain Res., 52, 309-321.

Ebels, I., A. Moree, A. De Hus-Citharel and A. Mozkowska (1979) A survey of some sheep pineal fractions and discussion on the possible significance of pteridines in these fractions in vitro and in vivo bioassay, J. Neural Transm., 44, 94-116.

Fahmy, I.G., and M.J. Fahmy (1963) British Empire Cancer Campaign for Research, Annual Report, Part II, pp. 130-131.

Gershenson, S. (1965) Induction of lethal mutations in Drosophila melanogaster, Genet. Res., 6, 157-162.

Lamotte, M. (1962) Initiation aux Méthodes Statistiques en Biologie, Masson, Paris, pp. 62-69.

L'Hélias, C. (1966) Induction de désordre tissulaire chez les insectes par altération de l'équilibre entre facteurs ptéridiniques et hormones de croissances, Ann. Endocrinol. (Paris), 27, 343-352.

L'Hélias, C. (1970) Altérations possibles dans la transmission des informations génétiques chez la Drosophile par injection d'extraits de chrysalides diapausantes $(\mathrm{Pb})$ traitées par des ptérines, Ann. Endocrinol. (Paris), 31, 578-581.

L'Hélias, C. (1972) Mutations et altérations dans la transmission des informations génétiques chez la Drosophile par injection d'extraits de chrysalides diapausantes (Pieris brassicae) traitées par des ptérines, Mutation Res., 14, 207-224.

L'Hélias, C. (1973) Mutations et altérations dans la transmission des informations génétiques chez la Drosophile par injection d'extraits de chrysalides diapausantes (Pieris brassicae) traitées par des ptérines, II. Variations dans l'expression des genes par addition d'hormones de croissance au traitement, Mutation Res., 20, 53-66.

L'Hélias, C. (1975) Hormones juvénile de Pieris brassicae diapausante et mutations, Ann. Endocrinol. (Paris), 35, 63-85.

L'Hélias, C., and J. Proust (1982) Mutations induced by a hormonal imbalance in Drosophila melanogaster, Mutation Res., 93, 125-148.

L'Hélias, C., I. Ebels and C.A. Salemink (1982) The influence of synthetic 6-L-erythrobiopterin on the neurosecretion of the pars intercerebralis of Pieris brassicae, 28, 459-463.

Lindsley, L., and E.H. Grell (1967) Genetic Variations of Drosophila melanogaster, Biology Division Oak Ridge National Laboratory, Publ. No. 627, Carnegie Institute Washington, DC.

Mathew, C. (1965) The production of recessive lethals by calf-thymus DNA in Drosophila, Genet. Res. Camb., 6, 163-174. 
Muller, H.J. (1951) Detection of mutations in the second chromosome by the use of Sifter stock, Drosophila Inform. Serv., 25, 117-118.

Muller, H.J. (1952) The standard error of the frequency of mutants some of which are of common origin (Abstr.), Rec.
Genet. Soc. Am., 21, 52.

Sapunov, U.B. (1981) The effect of juvenile hormone analogs on mutation frequency in Drosophila melanogaster, Drosophila Inform. Serv., 56, 116. 